\title{
POESÍA, EROTISMO Y RELIGIÓN
}

Gilberto Castrejón *

RESUMEN: Georges Bataille desarrolló una teoría del erotismo que lo vinculaba con la religión, ya que distinguió tres tipos de erotismo: de los cuerpos; de los corazones; y de lo sagrado. Su obra no deja de ser una fuente precisa para indagar cómo el erotismo resulta ser un "cuestionamiento del ser", una experiencia vinculada con otras como la poética o la religiosa. Este artículo presenta las relaciones entre poesía, erotismo y religión, desde la óptica filosófica de Bataille, haciendo ver cómo tales experiencias constituyen lo que el autor llamó "voluntad de lo imposible."

PALABRAS ClAVE: Poesía, erotismo, religión, experiencia soberana, voluntad de lo imposible.

RECEPCIÓN: 16 de febrero de 2010.

ACEPTACIÓN: 24 de mayo de 2011.
ABSTRACT: Georges Bataille developed a theory of eroticism closely tied to religion by distinguishing three different types: that of bodies, hearts, and spiritual. His work continues to be invaluable demonstrating how eroticism is self-questioning and tied to other experiences, poetic and religious. This article highlights the relationships between poetry, eroticism, and religion from Bataille's philosophical perspective, giving us insight into why such experiences constitute what he refers to as "the impossible".

KEYWORDS: Poetry, eroticism, religion, sovereignty, the impossible.

*Academia de Humanidades, Instituto Politécnico Nacional. 


\section{POESÍA, EROTISMO Y RELIGIÓN}

La poesía es una metafisica instantánea. En un breve poema, debe dar una visión del universo $y$ el secreto de un alma, un ser y unos objetos, todo al mismo tiempo.

Gaston Bachelard

El alma y el cuerpo son una y misma cosa. Pero nadie, hasta ahora, ha determinado lo que puede el cuerpo.

Baruch Spinoza

Existen experiencias que enfrentan al ser humano con algo que nunca termina por comprender, ¿será acaso posible acceder a un conocimiento fecundo y completo sobre experiencias como la poesía o la religión?

Hablar sobre la poesía, y aun la poesía misma, consisten también en hablar de algo que no se comprende. No es posible definir la poesía, como tampoco es posible definir la realidad. ¿Acaso lo es definir la vida, el amor, la muerte, la música, el dolor, el sueño? ¿Acaso es posible definir algo? ¿O todo se trata nada más que de una pequeña aproximación a lo inasible, nada más que el sueño de una formulación de lo inabarcable?

${ }^{1}$ Roberto Juarroz, Poesía y realidad, 2000, Valencia, Pre-Textos, p. 14.
Tratar de definir a la poesía como a la religión quizá sea una empresa fallida, pues ambas experiencias no quedan exentas de ese hálito metafísico e inconmensurable, que las acerca y emparenta a una experiencia fundamental humana: el erotismo. Georges Bataille es uno de los pensadores que más llamaron la atención sobre los vínculos implícitos entre estas tres experiencias humanas. Su obra analiza ciertos intersticios vinculados al cuerpo y al alma, sin tratarlos por separado, ya que según una tradición que se remonta desde Spinoza: "lo que es acción en el alma es también necesariamente acción en el cuerpo, y lo que es pasión en el cuerpo es también necesariamente 
pasión en el alma". ${ }^{2}$ Así, es menester afirmar con Bataille, que todo aquello que se ha dicho sobre el cuerpo no agota lo que éste es, pues el cuerpo supera todo conocimiento que se tiene de él, por algo la experiencia fundamental que es el erotismo, y que constituye una especie de "configuración" del cuerpo, constituye a su vez una experiencia análoga a la poética o religiosa. El erotismo libera de cierta forma al cuerpo, y a su vez, libera al espíritu, como lo hace la misma poesía. "Más real que los otros, el mundo de la poesía es la otra alternativa de salvación que nos queda, el último recurso de nuestra misteriosa necesidad de ser". 3 Así, poesía y religión son una vía a la salvación, pero la salvación lleva la necesidad de ser, en donde cuerpo y espíritu convergen, y la poesía como la religión imprimen a su vez la necesidad de autoafirmación, que en la experiencia que es el erotismo también se observa. Novalis bien lo supo: "La poesía es la religión originaria de la humanidad", por algo forma parte de esas experiencias humanas fundamentales como la religión y el erotismo. Es cierto que las religiones arcaicas se fundaron a partir de ciertas experiencias que el hombre primitivo conce-

${ }^{2}$ Gilles Deleuze, Spinoza: Filosofia Práctica, 2009, Barcelona, Tusquets Editores, trad. Antonio Escohotado, p. 28.

${ }^{3}$ Roberto Juarroz, op. cit., p. 32. bía como sobrenaturales, pues "la actitud que el hombre primitivo mantiene ante los fenómenos explica la forma creadora de mitos de su pensamiento". ${ }^{4}$ A su vez, muestran por qué la fundación de las primeras religiones guarda una relación estrecha con prácticas, ritos, etc., pues "la religión se deriva de la hechicería, de los rituales con los que se intentaba aplacar o hacer propicios a los elementos". ${ }^{5}$ De aquí que, si para el hombre primitivo la naturaleza no era algo impersonal, es decir, la veía no como un "ello", sino como un "tú", el carácter de los ritos y prácticas de las religiones arcaicas guarda una estrecha relación con ciertos puntos de contacto que el hombre tiene con la naturaleza, dígase en este caso concreto: el sexo, y por ello, tales ritos primitivos, que corresponden finalmente a una hierofanía, ${ }^{6}$ muestran algunas categorías esenciales del fenómeno religioso, lo que finalmente no queda exento también del ámbito poético.

Bataille siempre afirmó que las palabras estremecen, y lo hacen porque están ligadas al cuerpo, ¿habrá acaso

${ }^{4}$ H. y H. A. Frankfort, et. al, El pensamiento prefilosófico, 1986, México, FCE, trad. Eli de Gortari, p. 22.

${ }^{5}$ Camille Paglia, Sexual Personae, 2006, Valdemar, Madrid, trad. Pilar Vázquez Álvarez, p. 23.

6"(algo que manifiesta lo sagrado)", vid. Mircea Eliade, Tratado de historia de las religiones, 1997, México, Ediciones Era, trad. tomás Segovia. 
NOTAS

algunas otras experiencias soberanas ${ }^{7}$ tan exorbitantes como la religiosa, la erótica o la poética? Su obra da cuenta de cómo el erotismo no puede revelarse enteramente sin un halo poético, pues las imágenes eróticas, religiosas y poéticas estremecen; la poesía es una admonición a participar de cierto espectáculo exorbitante, de cierta experiencia soberana, pues incluso: "el instante poético tiene perspectiva metafísica". ${ }^{8}$ Y como tal, corresponde a una experiencia metafísica análoga a la religiosa, lo que seguramente no le fue indiferente a Bataille en su teoría sobre el erotismo. ${ }^{9}$

La experiencia interior del erotismo requiere, en el que la vive, una

${ }^{7}$ Bataille llama momentos soberanos (contenidos de experiencia) a "aquellas experiencias" que tanto que verifican la discontinuidad del hombre, como producen ciertas rupturas de pensamiento, $\mathrm{y}$ además: tales conductas son efusiones que implican un desgaste de energía, y cuyo efecto es una especie de iluminación interior. En este sentido, experiencias como la religión, el erotismo y la poesía corresponden a experiencias soberanas.

${ }^{8}$ Gaston Bachelard, La intuición del instante, 2002, México, FCE, trad. Jorge Ferreiro, p. 94.

${ }^{9}$ Para Georges Bataille lo sagrado en los sacrificios es análogo al sentimiento de lo divino en las religiones, pues como menciona: "La experiencia mística se da, me parece, a partir de la experiencia universal que es el sacrificio religioso", El erotismo, 1997, Tusquets editores, Barcelona, trad. Antoni Vicens y Marie Paule Sarazin, p. 38. De esta forma, se logra identificar que los arrebatos, el éxtasis implícito en la experiencia mística de las religiones, en cierto sentido también la cristiana, forman o se reconocen en una unidad que la vida erótica conlleva. La teoría del erotismo de Bataille distingue tres clases de erotismo: erotismo de los cuerpos; erotismo de los corazones; y erotismo de lo sagrado. sensibilidad no menos grande para la angustia, que funda el interdicto, que para el deseo que conduce a infringirlo. Es la sensibilidad religiosa, que liga siempre al deseo y al pavor, al placer intenso y a la angustia. $^{10}$

Erotismo, poesía y religión convergen en una dimensión básica del ser humano. Así, los momentos soberanos que son la religión, el erotismo y la poesía, instauran un sentimiento de estremecimiento y de revelación, implican un cierto delirio del ser, ya que, si tanto la religión como el erotismo justifican un juego alternativo: el del interdicto y la transgresión (la Ley y su ruptura), ${ }^{11}$ la poesía no queda

${ }^{10}$ Georges Bataille, ibid., p. 56.

${ }^{11} \mathrm{Cfr}$. "Si el terreno de lo sagrado tiene, de manera fundamental, una vinculación directa con el interdicto, entonces aquello que es el objeto de un interdicto llega a ser sagrado, parábola meramente cristiana, mas en ciertas religiones, en ritos como la fiesta, el sacrificio, la orgía, etc., se alcanza el punto culminante de la actividad religiosa, dando a estas realidades un sentido donde se "confunden" el interdicto y la transgresión. La religión cristiana habría de atacar la transgresión, pero de una manera tan brutal, que con ésta el apego a la ley no sólo sería un acto voluntario, sino impuesto, aunque la ley no sea precisamente una virtud de la naturaleza humana", Gilberto Castrejón, "El erotismo como experiencia vinculada al orden de lo sagrado", 2003, Dikaiosyne, año VI, núm. 11, Venezuela, pp. 11-22. Existe una especie de dialéctica del interdicto y la transgresión, en la cual siempre concurren fuerzas o elementos de atracción y de repulsión, y que en determinadas circunstancias ese elemento de atracción puede convertirse en elemento de repulsión y viceversa, ya que el hombre se enfrenta, en la experiencia de lo sagrado, a algo que le fascina, que le atrae, pero que a su vez le atemo- 
exenta de ello, pues "la poesía está fuera de la ley". 12

Para Bataille "la poesía es la voluntad de lo imposible"; él mismo tuvo que emprender un viaje sobre el cuerpo para descubrir el hilo conductor que une a la poesía con el erotismo, y a su vez, con la religión. Porque de cualquier manera toda poesía es erótica: "poesía es, sí, lucha con la carne, trato y comercio con ella, que desde el pecado - "la locura del cuerpo"- lleva a la caridad. Caridad, amor a la carne propia y a la ajena". ${ }^{13}$ Surge aquí un concepto que conduce a una reflexión sobre las posibilidades de expresión, sobre las posibilidades que lo erótico y lo religioso le brindan a la poesía: el amor como delirio y catalizador de la experiencia poética, así como de la experiencia erótica y religiosa, es decir, voluntad de lo imposible, como lo es todo amor. Así, en el vínculo entre poesía, erotismo y religión, aquél es sólo es una dispersión corporal, una "cópula espiritual":

Le vi en las manos como un dardo de oro largo, y en la punta

riza, y que además concibe como algo exorbitante, inconmensurable. ¿No es acaso el tipo de experiencia soberana análoga a la experiencia de la poesía o del erotismo?

${ }^{12}$ Georges Bataille, "La voluntad de lo imposible" en La felicidad, el erotismo y la literatura. Ensayos 1944-1961, 2004, Buenos Aires, Adriana Hidalgo editora, trad. Silvio Mattoni, p. 21.

${ }^{13}$ María Zambrano, Filosofia y poesía, 2006, México, FCE, p. 62. parecía tener un poco de fuego. Sentí que se metía varias veces por mi corazón, y que me llegaba hasta las entrañas. Al sentirla fuera de mí, y otra vez entrar, sentía que me llevaba consigo, dejándome extasiada por un amor grande hacia Dios. Era tan grande el dolor, pero más el deleite, que me hacía dar aquellos quejidos; era tan excesiva la suavidad, que aunque sintiera un grandísimo dolor, el deseo de seguir sintiéndolo no podía quitárseme [...] No es dolor corporal, sino espiritual, aunque no deja de participar en algo el cuerpo, yo diría que mucho. ${ }^{14}$

Incluso en los cánticos de San Juan de la Cruz, ${ }^{15}$ como en los relatos míticos, el erotismo y la religión están presentes, y son tales que no dejan de ser poesía. Pues la religión, el erotismo y la poesía constituyen una posibilidad, una vía de acceso a lo imposible, aunque precisamente lo imposible siempre "huya"; la religión busca a Dios, el erotismo al deseo permaneciendo deseo, la poesía no es más que la posibilidad de mirar a

${ }^{14}$ Adaptación del relato de una experiencia mística de Santa Teresa de Ávila.

${ }^{15}$ Tras de un amoroso lance, / y no de esperanza falto, / volé tan alto, tan alto, / que le di a la caza alcance.

1. Para que yo alcance diese / a aqueste lance divino, / tanto volar me convino / que de vista me perdiese; / y, con todo, en este trance / en el vuelo quedé falto; / mas el amor fue tan alto / que le di a la caza alcance. San Juan de la Cruz, Cántico Espiritual (fragmento). 
NOTAS

la "morada del ser", como la llamara Heidegger. De esta manera: poesía, erotismo y religión son, por tanto, "voluntad de lo imposible."

Como la religión, la poesía parte de la condición humana original -el estar ahí, el sabernos arrojados en ese ahí que es el mundo hostil o indiferente- $y$ del hecho que la hace precaria entre todos: su temporalidad, su finitud. Por una vía que, a su manera, es también negativa, el poeta llega al borde del lenguaje. ${ }^{16}$

¿Acaso no en ese borde del lenguaje, la experiencia soberana que es la poesía que hace estremecer, se fundamenta una condición humana exorbitante, original en cierta medida? La poesía, como mencionó alguna vez Bataille, "parte de lo conocido y conduce a lo desconocido", pues, como ya se dijo, la poesía es lo imposible o el acceso a éste, y por algo se refiere, como lo religioso, a una experiencia original y soberana. "La poesía produce penumbras, introduce el equívoco, aleja al mismo tiempo de la noche y el día-tanto del cuestionamiento como de la puesta en acción del mundo". ${ }^{17}$ Por ello:

Mientras todas las demás experiencias metafísicas se preparan en

${ }^{16}$ Octavio Paz, El arco y la lira, 2006, México, FCE, p. 142.

${ }^{17}$ Georges Bataille, "La voluntad de lo imposible", op. cit., p. 21. prólogos interminables, la poesía se niega a los preámbulos, a los principios, a los métodos y a las pruebas. Se niega a la duda. Cuando mucho necesita un preludio de silencio. ${ }^{18}$

La experiencia de la poesía es una experiencia soberana, hace estremecer a quien se enfrenta a ella; excede siempre lo ya dado; va más allá; se encuentra ligada a una dimensión de cambio, pero ahí mismo se dispersa. Si la poesía, como hubo de identificar Bataille, se encuentra ligada también a la carne, toda poesía es erótica, y la religión, al tener un vínculo fundamental con el erotismo, proporciona elementos para fundamentar que existe una estrecha conexión entre el mundo sagrado, el erotismo y la poesía. Basta señalar que: "sin duda, la religión es básicamente subversiva; desvía el cumplimiento de las leyes. Al menos, impone el exceso, el sacrificio y la fiesta, cuya culminación es el éxtasis". ${ }^{19}$ Por ello, poesía, erotismo y religión constituyen experiencias soberanas. "La poesía está cerrada para quien no se vea afectado por una emoción soberana, donde nada queda en reserva". ${ }^{20}$

${ }^{18}$ Gaston Bachelard, "Instante poético e instante metafísico" en La intuición del instante, op. cit., p. 93.

${ }^{19}$ Georges Bataille, Las lágrimas de Eros, 1997, Barcelona, Tusquets Editores, trad. David Fernández, p. 91.

${ }^{20}$ Georges Bataille, "De la edad de piedra a Jacques Prévert" en La felicidad, el erotismo y la literatura. Ensayos 1944-1961, 2004, Buenos Aires, Adriana Hidalgo editora, trad. Silvio Mattoni, p. 33. 
Esa emoción soberana no es más ni menos que la emoción religiosa, que la emoción erótica. La poesía, el erotismo y la religión comparten un principio motor y un fin; son experiencias interiores y revelan siempre algo que no es ni nunca será lo mismo. La poesía corresponde a un modo -lo más seguro natural- de expresión del erotismo y de la religión; es un espejo milenario que relata los intersticios del ser en su búsqueda de lo imposible.
Y aún suponiendo que un ángel me estrechara

súbitamente contra su pecho: mi ser quedaría extinguido

por su existencia más fuerte. Pues lo hermoso no es más que el comienzo de lo terrible que todavía podemos soportar, y lo admiramos tan sólo en la medida en que, indiferente, rehúsa destruirnos.

Todo ángel es terrible. ${ }^{21}$

${ }^{21}$ Rainer Maria Rilke, Elegías Duinesas en Nueva antología poética, 2002, Espasa Calpe, Biblioteca Austral, trad. Jaime Ferreiro Alemparte, p. 215. 
CITAM Derechos Reservados.

La reproducción total o parcial de este artículo se podrá hacer si el ITAM otorga la autorización previamente por escrito. 